\title{
XI International Mycological Congress: report of Congress action on nomenclature proposals relating to fungi
}

\author{
Tom W. May ${ }^{1}$, Scott A. Redhead ${ }^{2}$, Lorenzo Lombard ${ }^{3}$, and Amy Y. Rossman ${ }^{4}$
}

${ }^{1}$ Royal Botanic Gardens Victoria, Birdwood Avenue, Melbourne, VIC 3004, Australia; corresponding author e-mail: tom.may@rbg.vic.gov.au ${ }^{2}$ Ottawa Research and Development Centre, Science and Technology Branch, Agriculture and Agri-Food Canada, 960 Carling Avenue, K.W. Neatby Building, Ottawa, Ontario K1A 0C6, Canada

${ }^{3}$ Westerdijk Fungal Biodiversity Institute, Uppsalalaan 8, 3584 CT Utrecht, The Netherlands

${ }^{4}$ Department of Botany \& Plant Pathology, Oregon State University, Corvallis, OR 97333, USA

\begin{abstract}
Procedures, appointments and outcomes of the Fungal Nomenclature Session (FNS) of the $11^{\text {th }}$ International Mycological Congress (IMC11) are summarized, including the composition of the Fungal Nomenclature Bureau and the Nominating Committee of the IMC. Nearly 150 mycologists attended the FNS, at which formal proposals to amend Chapter $\mathrm{F}$ of the International Code of Nomenclature for algae, fungi, and plants (ICN) were debated. The 18 proposals considered included 10 "from the floor". Four proposals were withdrawn, two were sent to the Editorial Committee, five were sent to two Special-purpose Committees, four were rejected, and three were accepted (concerning: using the identifier in place of the author citation; mis-citation of identifiers; and indication of sanctioning). Proposals to amend Division III of the $I C N$ were deemed out of scope of the FNS because they did not relate to Chapter F. The two Special-purpose Committees authorized were: "DNA Sequences as Types for Fungi" and "Names of Fungi with the Same Epithet". Appointments made by the FNS included the Secretary of the Fungal Nomenclature Bureau for IMC12, and officers and members of the Permanent Nomenclature Committee for Fungi. Decisions and appointments of the FNS were ratified in a resolution accepted by the plenary session of the Congress.
\end{abstract}

Key words: Code, governance, Fungal Nomenclature Bureau, Fungal Nomenclature Session, ICN, Nomenclature Committee for Fungi. Special-purpose Committee.

Article info: Received 25 October 2018; Accepted 28 October 2018; Published 9 November 2018.

\section{INTRODUCTION}

Following changes to the International Code of Nomenclature for algae, fungi, and plants (ICN; Turland et al. 2018) at the XIX International Botanical Congress (IBC) in Shenzhen, July 2017, provisions of the $I C N$ that dealt solely with names of organisms treated as fungi were separated into a new section of the $I C N$, "Chapter F" (Hawksworth et al. 2017). In addition, it was agreed that future changes proposed to Chapter F would be dealt with by the Fungal Nomenclature Session of an International Mycological Congress (IMC) rather than the Nomenclature Section of an IBC. Procedures for introducing proposals to Chapter $\mathrm{F}$ were outlined by Hawksworth et al. (2017); proposals were published (Hawksworth 2018); a Synopsis of these proposals was presented (May \& Redhead 2018); and a pre-Congress Guiding vote on the proposals was held (May \& Miller 2018).

The Fungal Nomenclature Session (FNS) of the $11^{\text {th }}$ International Mycological Congress took place on 19 July 2018, in Room 201, Puerto Rico Convention Center, San Juan, Puerto Rico. Any person registered for that day of the Congress was entitled to attend the FNS and vote. Due to the compressed timelines for implementation of the new procedures for governance of fungal nomenclature, registration for the Fungal Nomenclature Session was not included on the Congress registration form. Members of the Fungal Nomenclature Bureau (FNB) were present at the registration desk on the first day of the Congress to answer questions about the FNS, and names of those intending to attend were added to a sign-up sheet. An online questionnaire was also used to register those intending to attend, and otherwise, on the day, attendees added their name to the sign-up sheet. A total of 149 people attended the FNS (Fig. 1). Although country was not recorded, those attending came from at least 20 countries.

\section{FUNGAL NOMENCLATURE SESSION PROCEDURES AND APPOINTMENTS}

Division III of the ICN (Provisions 4 and 8) sets out officers of the Fungal Nomenclature Bureau and the procedures for their appointment. The Fungal Nomenclature Bureau (Fig. 2) comprised Amy Rossman (Corvallis, USA, Chair), Tom W. May (Melbourne, Australia, Secretary), Scott A. Redhead (Ottawa, Canada, Deputy Secretary), Lorenzo Lombard (Utrecht, The Netherlands, Recorder), and five Deputy Chairs. The Deputy Chairs, as appointed by the FNS, were David Hawksworth (London, UK, Deputy Chair Emeritus), Meredith Blackwell (Columbia, USA), Pedro Crous (Utrecht, The Netherlands), Karen Hughes (Knoxville, USA), and Yu Li (Jilin, China; in absentia). In addition, Nicholas (Nick) J. Turland (Berlin, Germany), Rapporteur-général for the 2023 International Botanical Congress, attended as a non-voting advisor to the FNS, on the invitation of the International Mycological Association.

The Nominating Committee of the International Mycological Congress was proposed by the Chair of the FNS, in consultation with the other members of the FNB, and was accepted by the FNS. Composition of the Nominating Committee was as follows: Greg Mueller (Chicago, USA, Chair), Takayuki Aoki (Tsukuba, Japan), David Hawksworth (London, UK), Tatiana Gibertoni (Pernambuco, Brazil), and Marieka Gryzenhout (Bloemfontein, South Africa). The function of the Nominating Committee was to prepare a list of candidates to serve on the permanent Nomenclature Committee for Fungi (NCF), in consultation with the current Secretary of that Committee, and propose the Secretary of the Fungal Nomenclature Bureau for the next International Mycological Congress.

Procedures for the FNS are set out in Division III of the ICN. These procedures closely follow those of the Nomenclature Section 


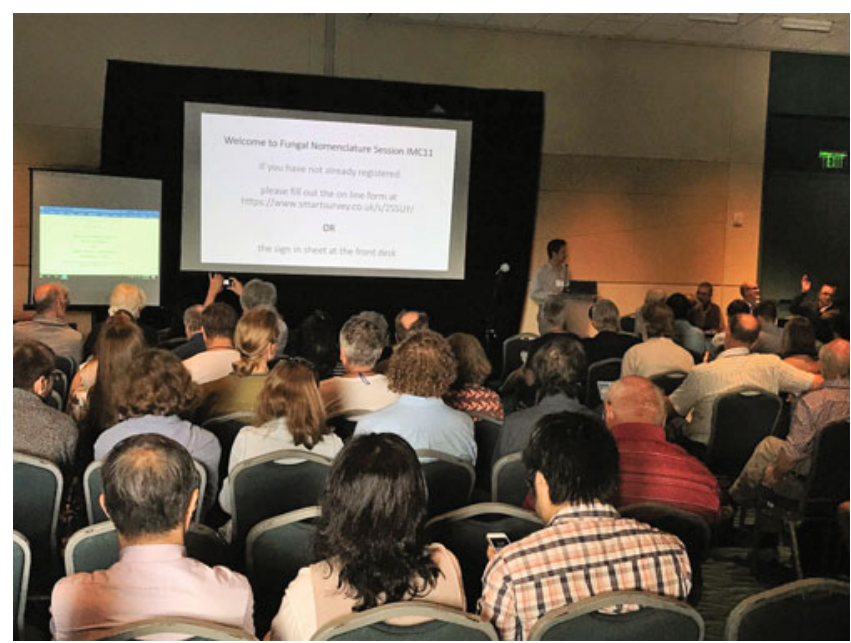

Fig. 1. Pedro Crous, Secretary-General, IMA, opening the Fungal Nomenclature Session, IMC11, Puerto Rico. Nicholas Turland (Rapporteur-général for 2023 International Botanical Congress) on far right, with raised hand. Photo: Wilhelm de Beer.

of an IBC, except that there are no institutional votes.

The FNS accepted the Shenzhen ICN as the basis for its deliberations. In the lead up to the FNS, proposed amendments to the $I C N$ were based on a draft version of the Shenzhen $I C N$, but discussions in the FNS used the final version, which was published in hard copy on 26 June 2018 and made available as an electronic version (http://www.iapt-taxon.org/nomen/main.php) on 27 June 2018.

It has been traditional at Nomenclature Sections of IBCs to deal with proposals in the sequence in which articles and other material to be amended (or added) appear in the $I C N$, and to aggregate proposals relating to one issue or concept (that may concern material present in different places in the $I C N)$. Due to the relatively small number of proposals, and in order to introduce the procedures, which would have been unfamiliar to many participants, proposals were dealt with in the following order, commencing with a relatively straightforward proposal: Prop. F-007 (on using the identifier in citation of names), Prop. F-005, F-006, F-012, F-013 and F-018 (all relating to 'DNA as type'), F-001 and F-002 (concerning Art. F.3 Note 2), F-003 and F-004 (on the citation of sanctioned names), F-014 (correctability of mis-cited identifiers), F-008, F-009 and F-015 (on the Guiding vote), F-016 and F-017 (introducing institutional votes), F-010 (establishing an Editorial Committee for Fungi), and F-011 (establishing a Special-purpose Committee on fungi named using the same epithet).

It is intended that proceedings of the FNS will be published in due course, based on transcripts of audio recordings of the Session, following the tradition of publishing the proceedings of Nomenclature Sections of IBCs, the most recent being that of the Melbourne IBC (Flann et al. 2014).

Each person present at the FNS (except for the Rapporteurgénéral) had one vote. Members of the FNB were eligible to vote, but, in order not to overly influence the voting, did not necessarily choose to vote on all matters. Voting in the FNS was initially by show of hands, but when the required majority for voting was not clear, there was a "division" whereby those casting a "no" vote passed by the counters separately from those casting a "yes" vote.

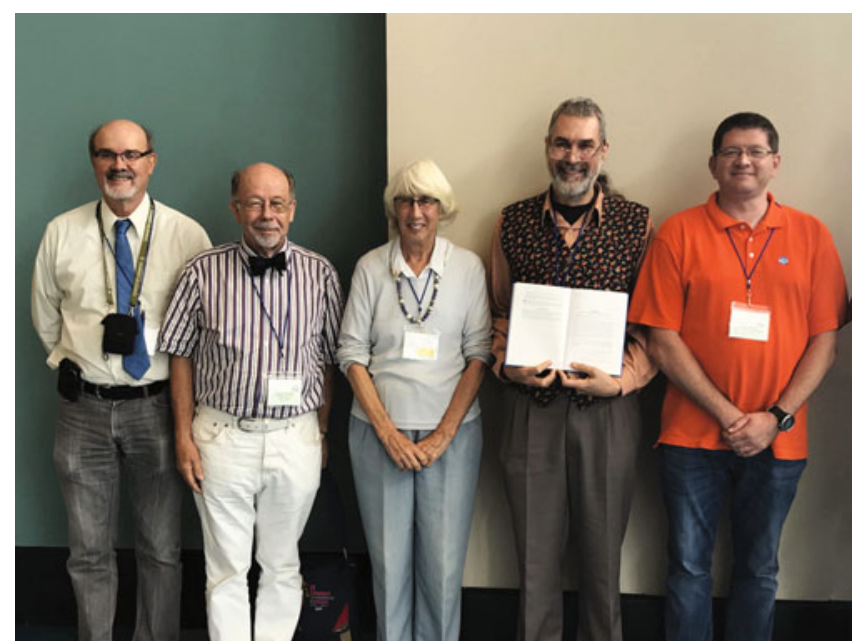

Fig. 2. Members of the Fungal Nomenclature Bureau, IMC11 (left to right): Scott Redhead (Deputy Secretary), David Hawksworth (Deputy Chair Emeritus), Amy Rossman (Chair), Tom May (Secretary, holding Chapter F of the Shenzhen $I C N)$, and Lorenzo Lombard (Recorder). Photo: Wilhelm de Beer.

The FNS accepted the candidates put forward by the Nominating Committee for the position of Secretary of the Fungal Nomenclature Bureau and the members of Nomenclature Committee for Fungi for the period 2018-2022 as follows:

Secretary of the Fungal Nomenclature Bureau for the XII International Mycological Congress, Amsterdam, 2022. - Tom W. May (Australia).

Nomenclature Committee for Fungi. - Scott A. Redhead (Canada, Chair), Tom W. May (Australia, Secretary), André Aptroot (The Netherlands), Z. Wilhelm de Beer (South Africa), Konstanze Bensch (The Netherlands/Germany), José Carmine Dianese (Brazil), Teresa Iturriaga (Venezuela/USA), Paul M. Kirk (UK), Roland Kirschner (Taiwan), James C. Lendemer (USA), Lorenzo Lombard (The Netherlands), Andrew M. Minnis (USA), Lorelei L. Norvell (USA), Luis A. Parra Sánchez (Spain), Shaun R. Pennycook (New Zealand), Andrea I. Romero (Argentina), Svengunnar Ryman (Sweden), Marco Thines (Germany), Dagmar Triebel (Germany), Zhuliang Yang (China), and Yi-Jian Yao (China).

\section{PROPOSALS FROM THE FLOOR}

New proposals ("Proposals from the floor"), which had not been included in the Synopsis of proposals, were accepted by the Secretaries up to the commencement of the FNS (8:00 h on Thursday 19 July 2018). This cut-off time was proposed to the FNS and accepted. Proposals from the floor (Table 1) were numbered continuing the sequence used in the Synopsis of proposals. Some proposals from the floor had appeared in publications prior to the FNS, while others were provided directly to the Secretaries.

\section{ACTIONS ON PROPOSALS}

There were 18 proposals on nine matters. Actions of the FNS are summarized in Table 2. Four proposals were withdrawn, two were sent to the Editorial Committee (one automatically, as it concerned 
Table 1. Proposals "from the floor" dealt with at the IMC11 Fungal Nomenclature Session.

\begin{tabular}{|c|c|}
\hline Proposal & Summary \\
\hline F-008 & $\begin{array}{l}\text { Amend Div. III, Prov. } 8.3 \text { by adding: " }(f) \text { Mycologists who have published at least one } \\
\text { nomenclatural novelty among organisms treated as fungi." }\end{array}$ \\
\hline F-009 & $\begin{array}{l}\text { Amend Div. III, Prov. } 8.3 \text { by removing "(b) Individual members of organizations affiliated with } \\
\text { the IMA" and rewording (a) accordingly. }\end{array}$ \\
\hline F-010 & $\begin{array}{l}\text { Create an Editorial Committee for Fungi (mirroring the Editorial Committee, as set out in } \\
\text { Div. III, Prov. 7.11). }\end{array}$ \\
\hline F-011 & $\begin{array}{l}\text { Create a Special-purpose Committee on Fungi named using the same Epithet for Asexual } \\
\text { and Sexual States, to report to the Fungal Nomenclature Session of the next International } \\
\text { Mycological Congress. }\end{array}$ \\
\hline F-012 & $\begin{array}{l}\text { In the event of proposals F-005 and F-006 being accepted, add Note to Chapter F of the Code } \\
\text { under Art. F.4.2 specifying: (1) registration of sequence-based names as "nom. seq." (nomena } \\
\text { sequentia) and (2) that such names do not have priority over names based on physical types } \\
\text { (including cultures) or illustrations. }\end{array}$ \\
\hline
\end{tabular}

In the event of proposals F-005 and F-006 not being accepted, add a new Note and an Example to Chapter F of the Code under Art. F. 5.5, specifying that designations [i.e. names that are not validly published] based on molecular sequence data are to be registered, but when released after effective publication such designations are to have "nom. seq." (nomen sequentium) appended.

Art F.5. Allow correctability of mis-cited identifiers, via additions to Art. F.5.1, new Art. F.5.6, F.5.7 and F.5.8; and including addition of Art. F.5.9 that correctability extends to type designations; and addition to Rec. F.5A.1 that authors "(c) upon publication of a name, supply an electronic version of the publication containing the name to the recognized repository that issued the identifier associated with the name."

Amend Div. III, Prov. 8.3 by removing clauses (a), (b) and $(c)$ and adding " $(f)$ Mycologists who have published at least one nomenclatural novelty among organisms treated as fungi, in a peerreviewed and indexed journal (only the authors of the nomenclatural novelty, who may differ from those of the publication)."

Amend Div., III, Prov. 8.9 to specify (a) Personal votes, and add: (b) Institutional votes, and (c) "Personal votes from nomenclature committees" including the Fungal Nomenclature Bureau (FNB), the Nomenclature Committee for Fungi (NCF), the International Commission on the Taxonomy of Fungi (ICTF), and mycologists on the General Committee (GC) and the Editorial Committee (EC). procedures for allocating Institutional votes for the Fungal Nomenclature Session.

F-018

Add a new Article in Chapter F concerning DNA sequences as types, incorporating proposals F-005, F-006 and F-012, with addition that "A name of a new taxon based on DNA sequence data as type": (1) "does not carry an author citation; instead, the unique registration identifier may be cited as reference. When a name based on DNA sequence data is epitypified with a physical type or illustration as defined in Art. 8.1-8.4, the authors of the epitypification become the authors of the name." and (2) "is not validly established unless the underlying raw data ... are deposited in a public repository and the unique identifier is cited in the protologue."

Proposed by

T.W. May \& A.N. Miller (2018, IMA

Fungus 9: (xv)-(xxi))

T.W. May \& A.N. Miller (2018, IMA

Fungus 9: (xv)-(xxi))

T.W. May

T.W. May

R. Lücking, P.M. Kirk \& D.L. Hawksworth (2018, IMA Fungus 9: 185-198)

Lücking, Kirk \& Hawksworth (2018, IMA Fungus 9: 185-198)

T.W. May, L.L. Norvell, K. Bensch, L. Lombard, D. Triebel \& Z.W. de Beer

J.C. Zamora

J.C. Zamora

J.C. Zamora

R. Lücking only an Example), five were sent to the two Special-purpose Committees that were established, four were rejected, and three were accepted (two after amendment). Proposals related to the following three matters were successful: using the identifier in place of the author citation; mis-citation of identifiers; and indication of sanctioning (Table 2). Proposals on DNA sequences as type that were included in the Guiding vote (in which they received more than $75 \%$ "No" votes) were reintroduced, but sent to a Special-purpose Committee, along with some other proposals on the same topic. For the two proposals concerning Art. F.3 Note 2, the first was sent to the Editorial Committee for clarification, and the second (to allow neotypification in place of lectotypification for sanctioned names) was rejected. Proposals on the Guiding vote, institutional votes, and an Editorial Committee for Fungi were deemed to concern governance (see below) and were either withdrawn or rejected. A proposal to establish a Special-purpose Committee on fungi named using the same epithet was accepted (see below).

\section{PROPOSALS ON GOVERNANCE}

Some proposals concerned matter in Division III of the ICN, which is the section covering governance, rather than Chapter $\mathrm{F}$ itself. Even though governance of the $I C N$ in respect of matter solely concerning names of fungi has been passed to the IMC, the wording of the new Provision in Division III is: "For proposals relating to the content of Chapter F, which brings together the provisions of this Code that deal solely with names of organisms treated as fungi (but excluding any other content), exactly the same procedures are to be followed .... The underlined phrase indicates that only Chapter $\mathrm{F}$ can be modified by action of the FNS at an IMC. This phrase was overlooked when the proposals to modify Division III were put forward. Division III, Provision 8.2 indicates that if there is doubt about "which proposals deal solely with names of ... fungi", a decision can be sought from the General Committee in consultation with the NCF, but there was not sufficient time to seek an opinion from these committees, 
Box 1: Key outcomes of the IMC11 Fungal Nomenclature Session

ICN amended so that:

- Errors in citation of identifiers (issued prior to publication of a nomenclatural novelty) are correctible

- Existing "validations" for nomenclatural novelties that were associated with mis-cited identifiers are to be treated as isonyms (as long as an identifier was issued prior to publication for the name as published, and the name is otherwise validly published)

- A new identifier must be obtained when validating a designation (an "invalid name"), even when that designation is associated with an existing identifier

- Authors are encouraged to deposit electronic versions (such as PDFs) of publications containing nomenclatural novelties and typifications with the repository that issued the relevant identifiers

- Sanctioning indicated only by “nom. sanct." (the “:” option was deleted)

- Author citation may be replaced by the name identifier — but authors are still to be cited for basionyms of new combinations

Special-purpose Committees to report to IMC12 on:

- DNA sequences as Types for Fungi

- Names of Fungi with the Same Epithet

\section{Editorial Committee}

- To clarify wording of Art. F.3 Note 2, on original material

\section{Chapter F of the ICN}

- New version to appear online and in IMA Fungus in early 2019

as some of the proposals from the floor were in the hands of the Secretaries only several days prior to the FNS. An opinion on whether or not the FNS may approve proposals to amend Division III will be sought from the General Committee prior to the next IMC, so that it is clear at that time if proposals to modify Division III can be dealt with at an IMC FNS, or otherwise must wait until the next IBC Nomenclature Section (which is the most likely interpretation).

There were five proposals concerning Division III: F-009 and F-015 on the Guiding vote; F-016 and F-017 introducing institutional votes; and F-010 establishing an Editorial Committee for Fungi, all introduced "from the floor". Of the five proposals, the proposers were present for two (F-008 and F-009), and these were withdrawn. The remaining three (F-015, F-016 and F-017) were voted on, and not approved. Nevertheless, it was considered useful to establish an "Editorial Committee for Fungi" (EdCF), which was proposed as an ad hoc committee, as allowed under Division III, Prov. 5.2.(e) and 8.1, and approved. The role of the EdCF will be to prepare a draft of changes to Chapter $F$ arising from the San Juan FNS, as a recommendation for the Editorial Committee. The revised Chapter $\mathrm{F}$ will be published in IMA Fungus, and any revisions will also appear in the on-line Shenzhen $I C N$, with indication that they arose from IMC11. Composition of the Editorial Committee for Fungi (EdCF) was agreed as: Tom W. May (Melbourne, Australia, Secretary Fungal Nomenclature Bureau), Scott A. Redhead (Ottawa, Canada, Deputy Secretary Fungal Nomenclature Bureau), Konstanze Bensch (The Netherlands/Germany), David Hawksworth (London, UK, Deputy Chair Emeritus Fungal Nomenclature Bureau), James C. Lendemer (New York, USA), Lorenzo Lombard (Utrecht, The Netherlands, and Nicholas J. Turland (Berlin, Germany, Rapporteur-général, Chair Editorial Committee). Membership is as approved by the FNS with addition of Lombard and Lendemer, who were co-opted after the Congress.

\section{SPECIAL-PURPOSE COMMITTEES}

Prior to the publication of the Shenzhen $I C N$, such as during the Shenzhen IBC Nomenclature Section itself, proposals to establish Special-purpose Committees (previously "Special Committees") were treated as proposals from the floor. However, Division III of the Shenzhen ICN (Prov. 8.5.(d)) contains expanded detail on procedures, and stipulates that one of the acceptable actions during the Fungal Nomenclature Section is to establish a Special-purpose Committee. Two Special-purpose Committees were proposed, and these were both authorized by the FNS; these will report to the IMC in 2022. Membership of the Special-purpose Committees will be appointed by the NCF in consultation with the General Committee (Div. III, Prov. 8.5.(d)), taking into account people present at the FNS who expressed interest in serving and any others who may be appropriate. The two Special-purpose Committees are:

- Special-purpose Committee on DNA Sequences as Types for Fungi

- Special-purpose Committee on Names of Fungi with the Same Epithet

There is already a Special-purpose Committee on DNA as Types, established at the Shenzhen IBC, to report to the 2023 IBC, dealing with all organisms covered by the ICN (algae, fungi, and plants). Close liaison between these two Committees with overlapping mandates will be necessary. In addition, the Shenzhen IBC established a "Special-purpose Committee on Pleomorphic Fungi (Art. 59)” (Turland et al. 2017). The scope of this Committee is identical to the Special-purpose Committee established at IMC11 to deal with "Names of Fungi with the Same Epithet"; specifically, cases where these names apply to different morphs (asexual/anamorph and sexual/teleomorph) of the same fungus (holomorph). It is more appropriate, now 
Table 2. Actions on nomenclature proposals considered by the Fungal Nomenclature Session of IMC11.

Abbreviations: ed.c. $=$ referred to the Editorial Committee; rej.g.v. $=$ rejected on Guiding vote; sp-p.c. $=$ referred to a Special-purpose Committee

\begin{tabular}{|c|c|c|}
\hline Proposal & $\begin{array}{l}\text { \% "No" } \\
\text { (Guiding vote) }\end{array}$ & Congress action \\
\hline \multicolumn{3}{|c|}{$\begin{array}{l}\text { Proposals submitted by } 1 \text { March 2018, included in Synopsis of proposals (May } \\
\text { \& Redhead 2018) }\end{array}$} \\
\hline F-001 & 37.2 & ed.c \\
\hline F-002 & 44.8 & rejected \\
\hline F-003 & 33.0 & accepted \\
\hline F-004 & 32.5 & ed.c \\
\hline F-005 & 88.8 & rej.g.v., reintroduced, sp-p.c \\
\hline F-006 & 86.1 & rej.g.v., reintroduced, sp-p.c \\
\hline F-007 & 66.8 & accepted after amendment ${ }^{1}$ \\
\hline \multicolumn{3}{|c|}{ Proposals "from the floor" (see Table 1) } \\
\hline F-008 & $\mathrm{n} / \mathrm{a}$ & withdrawn \\
\hline F-009 & $\mathrm{n} / \mathrm{a}$ & withdrawn \\
\hline F-010 & $\mathrm{n} / \mathrm{a}$ & withdrawn \\
\hline F-011 & $\mathrm{n} / \mathrm{a}$ & sp-p.c (as suggested) \\
\hline F-012 & $\mathrm{n} / \mathrm{a}$ & sp-p.c \\
\hline F-013 & $\mathrm{n} / \mathrm{a}$ & sp-p.c \\
\hline F-014 & $\mathrm{n} / \mathrm{a}$ & $\begin{array}{l}\text { accepted after amendment and withdrawal of } \\
\text { certain portions }{ }^{2}\end{array}$ \\
\hline F-015 & $\mathrm{n} / \mathrm{a}$ & rejected \\
\hline F-016 & $\mathrm{n} / \mathrm{a}$ & rejected \\
\hline F-017 & $\mathrm{n} / \mathrm{a}$ & rejected \\
\hline F-018 & $\mathrm{n} / \mathrm{a}$ & withdrawn \\
\hline
\end{tabular}

${ }^{1}$ Proposal F-007 was amended so that the first sentence became an Article, and the second sentence a Recommendation, with addition of words "already published" before name of organisms, and "subsequent to the protologue" after "may be used".

${ }^{2}$ In proposal F-014, proposed additions of Art. F.5.9 and to Rec. F.5A in the original proposal were accepted, but the proposal was otherwise amended by: (a) deleting proposed additional wording under Art. F.5.1., and proposed new Art. F.5.6 and F5.7; (b) withdrawing proposed new Art. F.5.8; and (c) adding the following wording: F-014(1) "Art. F.5.1 bis. When the identifier issued for a name by a recognized repository is cited incorrectly in the protologue, that name may nevertheless be validly published, provide that the identifier for the name was issued prior to valid publication. The identifier cited in the protologue is treated as a correctable error" and F-014(2) "Art. F.5.1 ter. An identifier remains associated with the name or designation for which it was issued. In order for a designation to become validly published, a separate identifier must be obtained."

that Chapter $\mathrm{F}$ contains material relating only to fungi, that a Special-purpose Committee dealing with the same epithet issue reports to the FNS of the next IMC, rather than the next IBC Nomenclature Section. Karen Wilson (Secretary, General Committee) has advised that replacing the Special-purpose Committee set up at the XIX IBC by the Special-purpose Committee on Names of Fungi with the Same Epithet (reporting to the next IMC) is a sensible action, which can be formally ratified when the composition of the two Special-purpose Committees is discussed with the General Committee.

\section{RESOLUTION AND THE NEW WORDING OF ICN CHAPTER F}

As its final item of business, the FNS accepted a motion from the Secretary that the President and the Secretaries be instructed to present to the President of the International Mycological Association (IMA) a resolution on behalf of the Session to the effect that the decisions and appointments of the FNS be approved. At the closing ceremony (plenary session) to the Congress, which began at 17:00 h local time on 21 July 2018 , the following resolution was accepted:

"The XI International Mycological Congress resolved that the decisions of its Fungal Nomenclature Session with respect to the International Code of Nomenclature for algae, fungi, and plants, as well as the appointment of the Secretary of the Fungal Nomenclature Bureau, and officers and members of the Permanent Nomenclature Committee for Fungi, made by that Session during its meeting, 19 July 2018, be accepted."

The wording of Chapter F of the Shenzhen $I C N$ will be amended in accordance with this resolution, by the EdCF, as a recommendation to the full Editorial Committee of the ICN. It is expected that the new version of Chapter $\mathrm{F}$ will be ready in early 2019, for publication in IMA Fungus. The on-line version of the $I C N$ will also be amended accordingly, with an indication that the changes arose from IMC11.

Amendments to the $I C N$ became effective immediately upon acceptance of this resolution; they are not dependent upon publication of the present report nor upon publication of the revised version of Chapter F of the Shenzhen ICN. New and amended rules are retroactive to the starting-point for fungi, 1 May 1753 (Art. F.1 and 13.1(f)), unless expressly limited. The only decision made in San Juan that involved a date limitation was in relation to correctability of identifiers for typifications, because mandatory citation of identifiers for typifications comes into force on 1 January 2019.

\section{RECOMMENDATIONS FOR FUTURE FUNGAL NOMENCLATURE SESSIONS}

On the whole, given the short lead time from the Shenzhen IBC (which approved the concept of a FNS) and the San Juan IMC, the inaugural FNS operated relatively smoothly. There is scope prior to the next IMC to provide a timetable and explanatory material (e.g. in relation to the publication of proposals and the Guiding vote) well-ahead of the Congress. For the next FNS, it is recommended that: (1) the FNS is a separate session within the Congress programme, not overlapping with symposia or field excursions of the Congress; (2) there is an option to register for the FNS in the Congress registration form, so that it is clear ahead of time how many people will be attending; and (3) proposals from the floor are only allowed up to the commencement of the FNS, except where they relate to ones that have already been accepted during the Session, and deal with technical aspects of such proposals (rather than intent), so as to avoid any unintended consequences of a particular wording that had been accepted. 


\section{ACKNOWLEDGEMENTS}

We thank the IMC11 Organizing Committee, particularly the Chair, Sharon Cantrell (Gurabo, Puerto Rico), along with Astrid Concepción (San Juan, Puerto Rico), for making available facilities for the FNS; Werner Greuter (Berlin) for suggesting the concept of Chapter $\mathrm{F}$, which facilitated dealing with fungi-specific aspects of the $I C N$; Nicholas Turland (Berlin), Rapporteurgénéral for the XX International Botanical Congress, for his generous support in the lead up to and during the FNS, and his helpful feedback on this report; Dominik Begerow (Bochum) for timely updates to the International Mycological Association website; Greg Mueller (Chicago) and the other members of the Nominating Committee for taking time out during the Congress to prepare their recommendations; Wilhelm de Beer (Pretoria) for co-ordinating the compilation of lists of attendees, and providing photographs; and Teresa Iturriaga (Ithaca), Ihan du Plessis (Stellenbosch), Ludovic Le Renard (Vancouver) and Wilma Nel (Pretoria) for assisting with the roving microphones during the Session.

\section{REFERENCES}

Flann C, Turland NJ, Monro AM (2014) Report on botanical nomenclature - Melbourne 2011. XVIII International Botanical Congress, Melbourne: Nomenclature Section, 18-22 July 2011. PhytoKeys 41: 1-289.
Hawksworth DL (ed.) (2018) Proposals for consideration at IMC11 to modify provisions solely related to fungi in the International Code of Nomenclature for algae, fungi, and plants. IMA Fungus 9: (i)-(vii).

Hawksworth DL, May TW, Redhead SA (2017) Fungal nomenclature evolving: changes by the 19th International Botanical Congress in Shenzhen 2017, and procedures for the Fungal Nomenclature Session at the $11^{\text {th }}$ International Mycological Congress in Puerto Rico 2018. IMA Fungus 8: 211-218.

May TW, Miller AN (2018) XI International Mycological Congress: Guiding Vote on nomenclature proposals to amend Chapter F of the International Code of Nomenclature for algae, fungi, and plants. IMA Fungus 9: (xv)-(xxi)

May TW, Redhead SA (2018) Synopsis of proposals on fungal Nomenclature: a review of the proposals concerning Chapter $\mathrm{F}$ of the International Code of Nomenclature for algae, fungi, and plants submitted to the XI International Mycological Congress, 2018. IMA Fungus 9: (ix)-(xiv).

Turland NJ, Wiersema JH, Monro AM, Deng Y-F, Zhang L (2017) XIX International Botanical Congress: report of Congress action on nomenclatural proposals. Taxon 66: 1234-1245.

Turland NJ, Wiersema JH, Barrie FR, Greuter W, Hawksworth DL, et al. (2018) International Code of Nomenclature for algae, fungi, and plants (Shenzhen Code) adopted by the Nineteenth International Botanical Congress Shenzhen, China, July 2017. [Regnum Vegetabile no. 159.] Glashütten: Koeltz Botanical Books. 